\title{
Acne Facial Skin Care with the Beauty Electrical Tool Through Problem Based Learning
}

\author{
Nia Kusstianti, Luthfiyah Nurlaela, Ekohariadi \\ Home Economics Department \\ Universitas Negeri Surabaya \\ Surabaya, Indonesia \\ niakusstianti@unesa.ac.id
}

\begin{abstract}
This research aims to know whether there is a difference between using problem based learning and direct learning instruction towards students' learning result of acne facial skin care with a beauty electrical tool. This research is an experimental one using quantitative approach with post test only control design. The research result revealed that the students' learning result with problem based learning is better than that with direct learning instruction.
\end{abstract}

Keywords-problem-based learning, acne facial skin care, beauty electrical tool

\section{INTRODUCTION}

Education is conducted to prepare the students to become persons of the society that are independent. Independent person is a person that is able to think, to find and to create something new, to see any problems as well as to find out some ways of new outcomes that are reasonable.

Teachers are considered to have an important role in educating students to be independent human beings. That is why teachers have got many suggestions even some criticism about how to teach some materials that is not only to cover some information or any concepts. The information or concept that is accepted by the students might be less worthy even not worthy at all if the thing is only communicated by the teacher through one way of direction. Information or concept is one thing that is very important. However, it does not depend on the concept itself, but is laid on how the concept is understood by the students. The importance of comprehending the concept in the process of teaching and learning influences behavior very much, decision, and some ways to solve the problems so that a meaningful learning occurs.

According to Arends "it is strange that we expect students to learn yet seldom teach them about learning, we expect students to solve problems yet seldom to teach them about problem solving" [1], which means in teaching process, a teacher always asks his students to study but seldom gives ways on how to study well. The teacher also asks his students to solve a problem but he seldom teaches how the students should solve the problems.

The problem now is how to find the best way to convey the concepts taught so that students can use and remember longer the concepts and relate them in real life. How can a good teacher choose the right model of learning and related to problem solving?

A learning model which relates with ways to solve a problem is a problem based learning (PBL) model. This kind of learning model is based on some problems that need an authentic investigation, namely a research which needs a real solution from real problems. This learning model involves students to solve a problem through the stages of scientific method so that students can learn the knowledge related to the problem and also have the skills to solve the problem [2].

Problem based learning is an interaction between stimuli with its responds, a connection between two ways of learning and the environment [3]. The environment gives the outcomes, namely a help and the problems, while the brain system functions to explain the help effectively so that the problems faced can be investigated, scored, analyzed as well as given the solution well. The students' experience got from the environment will give them materials to get an explanation and become guidance and the purpose of the learning.

Problem based learning is an instructional approach that provides learners with opportunities to identify solutions to real-world problems [4]. The student appears to have to uncover new knowledge, knowledge that is new to them, even though it maybe already known to the specialist. Therefore, Problem Based Learning potentially can place the learner in a position similar to that of scientist and scientific process. [5].

Problem based learning is not designed to help teachers provide as much information to students as possible. It is developed to help students develop thinking skills, problem solving, and intellectual skills; learning the various roles of adults through their involvement in real-life experiences or simulations; and become independent learners [6].

Problem based learning as an instructional method in which students learn through facilitated problem solving that centers on a complex problem that does not have a single correct answer [7]. She noted that students work in collaborative groups to identify what they need to learn in order to solve a problem, engage in self-directed learning, apply their new knowledge to the problem, and reflect on what they learned and the effectiveness of the strategies employed.

Through the problem based learning, the students can arrange their knowledge themselves and expand the inquiry and their skills higher so that it is hoped that it can increase the learning result. Bloom classified the learning process become three ways, namely cognitive, affective, and psychomotor. Cognitive relates with the learning result of intellectual, affective relates with behavior and psychomotor relates with the learning result of skill. With Bloom classification, teachers have relied on Bloom's taxonomy to 
guide how they write learning outcomes, structure learning activities, and assess student learning [8].

Facial skin care is a university subject that includes theory and practice with a material that is the basic knowledge about skin, skin problems, skin diagnose, knowledge about tools and materials for the skin care, skin care problems, knowledge about beauty electricity tools and the care of face skin when having problems using electricity tools.

The model of problem based learning is predicted exactly to apply as an alternative of learning model on the treatment of the face skin that has problems. Through problem based learning, it is hoped that students will be able to increase the ability to think by solving the existing skin problems, then to expand their intellectual skills through some steps correctly that accord with the problems so that it can increase the learning result.

\section{METHOD}

The kind of research used is experiment by using quantitative approach. A research design that is used is Posttest Only Control Design as in (1).

$$
\mathrm{X} \rightarrow \mathrm{O}
$$

\section{$X$ : Treatment \\ $\mathrm{O}:$ Post Test}

In this design, there are two groups, namely experimental group and control group. Experimental group is a group that is given treatment, namely the application of problem based learning, while control class is a group given no treatment, using the learning they used to experience, namely direct learning model. The object of this research is students of Beauty Education batch of 2012 that are having a lesson of the treatment of face skin, they are 55 students, consists of 27 students as the experimental class (Class A) and 28 students as control class (Class B). A technique of collecting the data was capability test of problem solving and test of learning result with the scoring and questionnaire to get a data about students' responses towards the application of problem based learning. To test the difference of score between learning result on the experimental class and control class t-test was used. The hypothesis being used in this research is the learning result by applying problem based learning is better compared to the learning result of students that apply direct learning model on the competency of acne face skin treatment by using the beauty electrical tool.

\section{RESULT AND DISCUSSION}

Problem based learning is applied on the treatment of acne face skin by using the electricity tool by making the students used to think critically so that it will be easier in solving a problem that will affect the improvement of their cognitive. Problem based learning gives the students more chance to analyze and overcome any existing problems. Indeed, problems of skin vary so that it needs the comprehension and ability of students to analyze the problem and then to prepare and to decide the kind of treatment that is suitable with the problem. Finally, the students can conduct the treatment that is suitable with the skin problems.
Test of ability to solve the problem is only given to the experimental group, namely group that is taught by using problem based learning. The mean got from the test of solving the problem is 82.6. This means the students have understood the problem that is given well, namely they can diagnose acne face skin. The students understand how to make a plan to solve problem, namely by identifying the healthy and the secure of working, identify the cosmetics material and the kind of electricity tool that is needed to treat the acne face skin that is suitable with diagnose result. Finally, the students can apply the plan by making or arranging steps of treatment for acne face skin by using electricity tool. After all the steps are applied, students can recheck by checking all the steps that has been made to be applied or to be practiced. This means that the students understand the problem of face skin that is given. Thus, it can be concluded from the test of ability to overcome the problems that the students can solve the skin problems that is given well.

Problem based learning is applied to the experimental class (Class A) and the model of direct learning to the control class (class B). the test score from the learning result that is got from the two class is the combination between the test score of the learning result (cognitive ability) and working test of the learning result (psychomotor ability). The mean result score of the students by applying the problem based learning is 83.82 while the mean score of the learning result with the direct learning is 80.22 .

The score of t-test is 3.78 . With the class amount of experimental class $\mathrm{df}=\mathrm{n}-1=28-1=27$, in fact the significant result is 0.001 , namely under 0.005 . With the criterion if $\mathrm{t}$ counted is more than t-table, Ho is rejected and $\mathrm{Ha}$ is accepted. So it can be concluded that there is a difference of learning result significantly between applying problem based learning and direct learning model.

The problems given in the problem based learning is $82.1 \%$. The evaluation given by the lecturer is $96.4 \%$, suitable with the capability of students working result. Problem based learning can make the students active and more creative. This is proved with $100 \%$ of the students' gave positive response. $78.6 \%$ of them want the same learning will be conducted to the learning with different topic. It can be concluded that students give positive response towards problem based learning and it will be very good applied on the treatment of problem face skin.

\section{CONCLUSION}

The model of problem based learning applied on the problem face skin care make the students solve the skin problems given well. The students can decide the tool and cosmetics materials needed and decide the application of treatment that is suitable with the problem.

The problem based learning can be applied on the competence of acne facial skin care with the electricity tool. It can also be applied to other competence or lesson of face skin care. Problem based learning should be applied in other lessons, so that it can make students more creative and can improve their ideas in solving the skin problems.

\section{REFERENCES}

[1] Arends. Richard, Classroom Instructional Management. New York : The Mc Graw-Hill Company, 1997. 
[2] Ibrahim. Muslimin, Pembelajaran Berdasarkan Masalah. Surabaya University Press, 2005.

[3] Sudjana. D, Metode dan Teknik Pembelajaran Partisipatif. Bandung : Falah Production, 2001.

[4] Hartman, Katherine. Effectiveness of Problem-Based Learning in Introductory Business Courses. Journal of Instructional Pedagogies, v12 Sep 2013.

[5] Ibrahim. M, and Nur. M., 2000. Pengajaran Berdasarkan Masalah. Surabaya: University Press, 2000.

[6] Wendy Hillman, Learning How to Learn : Problem Based Learning. Australian Jounal of Teacher Education, 2000, Volume 28. Issue 2.

[7] Hmelo-Silver,C.E, Problem-Based learning: What and how do students learn? Educational Psychology Review, 16(3), 2004, 235 266.

[8] Claudia J Stanny, Reevaluating Bloom's Taxonomy : What Measurable Verbs Can and Cannot Say about Student Learning. Education Science 2016, Volume 6. Issue 4. 